\title{
The External and Internal Factors That Influence the Choice of Foreign Entry Modes at Wuhan Iron and Steel Corporation
}

\author{
Fidelys Ravelomanana1, Liang Yan'1, Christophe Mahazomanana', Leoncine Paul Miarisoa ${ }^{2}$ \\ ${ }^{1}$ School of Economics and Management, China University of Geosciences (Wuhan), Wuhan, China \\ ${ }^{2}$ Lingnan (University) College, Sun Yat-sen University, Guangzhou, China \\ Email: fidelys@hotmail.com, mahazomanana@hotmail.com, mleoncine@hotmail.com
}

Received 10 November 2014; revised 6 December 2014; accepted 23 December 2014

Copyright (C) 2015 by authors and Scientific Research Publishing Inc.

This work is licensed under the Creative Commons Attribution International License (CC BY).

http://creativecommons.org/licenses/by/4.0/

(c) (i) Open Access

\begin{abstract}
The purpose of this research is to increase our understanding of how the process of internationalization is intertwined with the set of external and internal factors that determine choice of foreign entry mode at Wuhan Iron and Steel Corporation (WISCO). To satisfy the purpose of our study, the following research question was addressed: RQ: How can the influence of external and internal factors on WISCO's choice of foreign entry mode be described? In this paper, a selection of the literature and existing research on the choice of foreign entry modes are reviewed, and at the same time, we develop a conceptual framework based on the theories and references that were reviewed, and then going more in detail into the external and internal factors influencing the choice of foreign target market. A summary of conceptual framework was presented, which then will be used as a basis for the data collection. Data collected on the company WISCO that was analyzed against existing theories brought us to certain conclusions which we present at the end of this paper. The fact that a single case would not allow us to generalize is not overlooked. However, indepth analysis of the company WISCO has shed light on aspects of internationalization choice of entry modes which deserve consideration.
\end{abstract}

\section{Keywords}

Internationalization, Choice of Foreign Entry Modes, The Internal and External Factors

\section{Introduction}

In an increasingly globalizing economy, many firms are driven by the need to expand business to international

How to cite this paper: Ravelomanana, F., Yan, L., Mahazomanana, C. and Miarisoa, L.P. (2015) The External and Internal Factors That Influence the Choice of Foreign Entry Modes at Wuhan Iron and Steel Corporation. Open Journal of Business and Management, 3, 20-29. http://dx.doi.org/10.4236/ojbm.2015.31003 
markets. The decision making process regards the internationalization evolution as the choice of market, timing and mode of entry.

According to De Búrca, Fletcher \& Brown (2004) [1], decisions as to the form of market entry, for example, exporting, joint ventures or franchising, logically follow the decision as to the most appropriate market to enter. However, market selection and entry mode are closely linked due to the attractiveness of markets is influenced by the strategic thrust of the corporation, competitive action in those markets and government regulation relating to the possible forms of foreign entry. Deciding on the most appropriate form of market entry involves understanding each of the various modes available and understanding the conditions under which one mode might be more suitable than others.

Root (1994) [2] stated that to managers, planning entry strategies may appear to be something only large companies can afford to do; these managers identify such planning with elaborate research techniques that are applied by specialists to a massive body of quantitative data. However, this is a misconception of the entry plan process. The truly important is the idea of planning entry strategies. Once management accepts this idea, it will find ways to plan international market entry; how limited the company resources ever may be. Without an entry strategy for a product or target market, a company only has a simple "sales" approach to foreign markets.

The companies may face a large number of problems when turning international. What are the major obstacles for internationalization experienced by companies and do this influence their choice of foreign entry modes has not been sufficiently studied in the past.

The purpose of this research is to increase our understanding of how the process of internationalization is intertwined with the set of external and internal factors that determine choice of foreign entry mode at Wuhan Iron and Steel Corporation (WISCO). To satisfy the purpose of our study,the following research question was addressed: RQ: How can the influence of external and internal factors on WISCO's choice of foreign entry mode be described?

\section{Literature Review}

In this part, a selection of the literature and existing research on the choice of foreign entry modes are reviewed, and at the same time, we develop a conceptual framework based on the theories and references that were reviewed, and then going more in detail into the external and internal factors influencing the choice of foreign target market. At the end of this part, some of the reviewed theories will be used to develop a summary of conceptual framework, which then will be used as a basis for the data collection. We only present below the literature that will be used to develop a summary of conceptual framework.

\subsection{Choice of Foreign Entry Modes}

According to Root (1994) [2], entry strategy for international markets is a comprehensive plan. It sets forth the objectives, goals, resources, and policies that will guide a company's international business operations over a future period long enough to achieve sustainable growth in world markets. For most companies the entry strategy time horizon is from three to five years, which is the typical time period for achieving enduring market performance. Many managers see the company's entry strategy as if it were a single plan; it is actually a composite of several individual product/market plans. Managers need to plan the entry strategy for each product in each foreign market.

The product/market entry strategies require decisions, as seen in Figure 1, on 1) the choice of a target product/market, 2) the objectives and goals in the target market, 3) the choice of an entry mode to penetrate the target market country, 4) the marketing plan to penetrate the target market, and 5) the control system to monitor performance in the target market. The elements in Figure 1 are shown as a logical sequence of activities and decisions, but the design of a market entry strategy is actually interactive with many feedback loops. Evaluation of alternative entry modes, for instance, may force a company to revise its target market's objectives or goals, and may even initiate the search for a new target market. (Ibid.)

According to Root (1994) [2], international entry strategy is a comprehensive plan and it sets forth objectives, goals, resources and policies that will guide the international business activities. The selection of an entry mode involves following decisions:

1) Choice of a target product/market

2) Objectives and goals in the target market

3) Choice of an entry mode to penetrate the target market country 


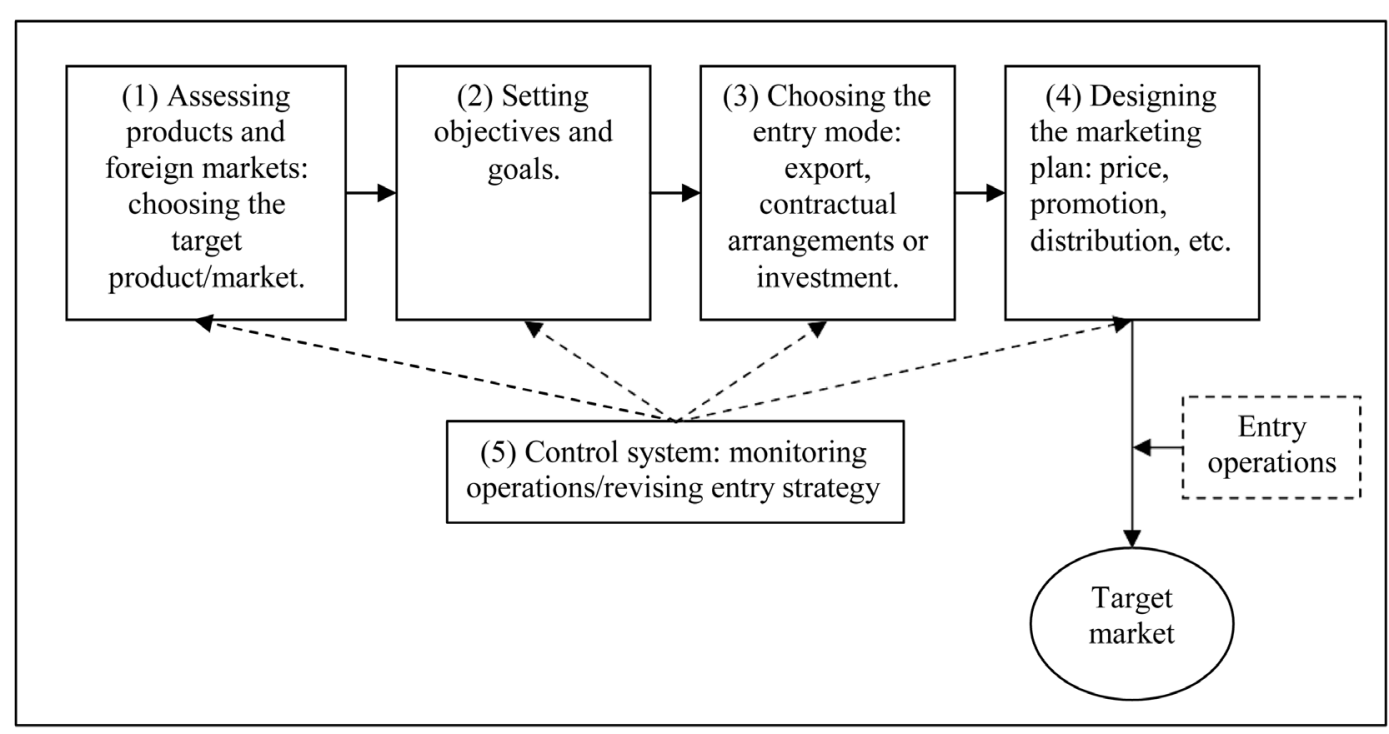

Figure 1. Elements of the entry strategy. Source: Root (1994), Entry strategies for International markets.

4) Marketing plan to penetrate the target market

5) Control system to monitor performance in the target market

\subsection{Types of Foreign Entry Modes}

Brassington \& Pettitt (2000) [3] pointed out that the classification of market entry modes is not easy, but one possible classification can be seen in Figure 2. There are many relevant criteria to take into consideration. For example, the level of investment involved and whether it is indirect or direct and whether the goods or services are produced at home or abroad. Other things that need to be considered are if the exporter should deal directly with the buyer, as well as if the transaction involves exporting goods and services, knowledge and expertise or investment.

The classification of foreign market entry modes is not easy and there are many relevant criteria to take into consideration. Brassington \& Pettitt (2000) [3], Wild, Wild \& Han (2003) [4], and Armstrong G. \& Kotler P. (2005) [5] presented several different types of foreign entry mode:

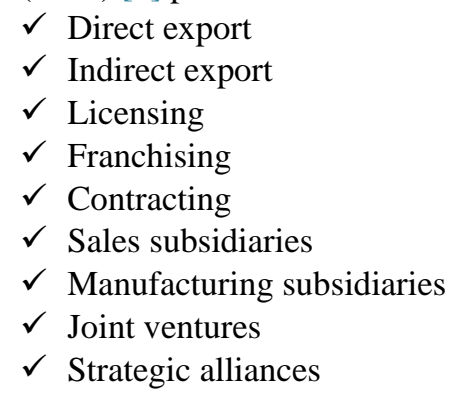

\subsection{External Factors Influencing Choice of Foreign Entry Modes}

According to Hollensen (2001) [6], there are following external factors influencing company's choice of foreign entry mode:

$\checkmark$ Socio-cultural distance

$\checkmark$ Country risk and demand uncertainty

$\checkmark$ Market size and growth

$\checkmark$ Direct and indirect trade barriers

$\checkmark$ Competitive environment

$\checkmark$ Small number of relevant intermediaries available 


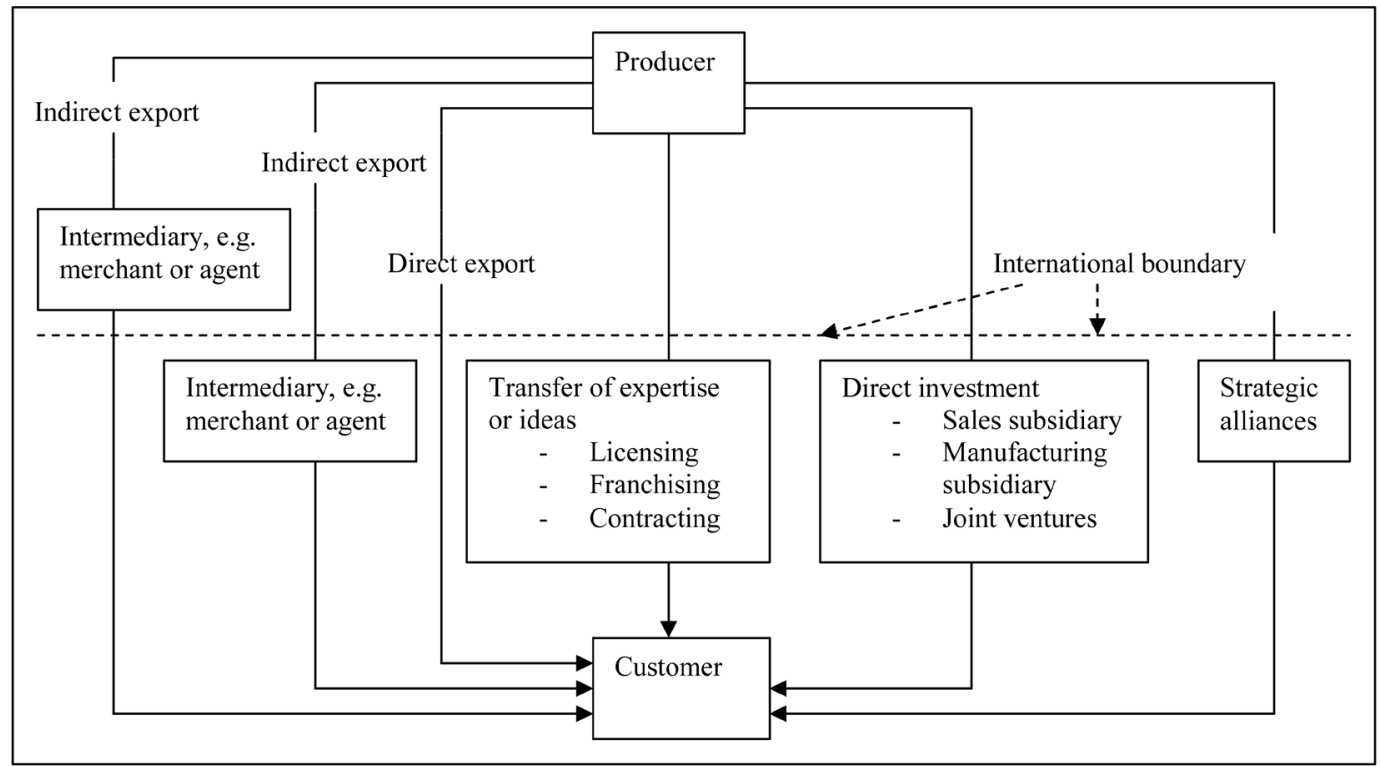

Figure 2. Market entry methods. Source: Brassington \& Pettit (2000), Principle of Marketing.

De Búrca, Brown \& Fletcher (2004) [1] pointed out the importance of the following additional factor for the choice of foreign entry mode:

$\checkmark$ Laws and regulations

Root (1994) [2] also took up an additional factor that influenced the choice of foreign entry modes:

$\checkmark$ Geographical distance

\subsection{Internal Factors Influencing Choice of Foreign Entry Modes}

According to Brassington \& Pettitt (2000) [3], when the company decided which markets to enter, it must then decide how to enter them. A number of factors influence the choice of foreign market entry mode:

$\checkmark$ Speed

$\checkmark$ Costs

$\checkmark$ Payback

$\checkmark$ Long-term objectives

Furthermore according to Hollensen (2001) [6], there are some additional factors influencing company's choice of foreign entry modes:

$\checkmark$ Company size

$\checkmark$ International experience

$\checkmark$ Product complexity and differentiation

$\checkmark$ Risks

$\checkmark$ Control

$\checkmark$ Flexibility

De Búrca, Brown \& Fletcher (2004) [1] took up the importance of company management influencing the choice of a specific foreign entry mode:

$\checkmark$ Managerial Reasons

Fredrik \& Webster (1992) [7] also pointed out the importance of the following factor for the choice of foreign entry modes:

$\checkmark$ Relationships

\subsection{Summary of Conceptual Framework}

In order to further display the main factors influencing choice of foreign entry modes, we have summarized the factors to form our conceptual framework in Figure 3. 


\section{Methodology}

According to Yin (2003) [8], the research approach can be quantitative or qualitative. By choosing one of these approaches the researcher will know how to treat and analyze the gathered information. The qualitative approach has been used in this paper, since deeper and broader understanding is aimed to be reached within the research area.

In order to ensure the validity of this research, the interview guide was formulated from the emerged frame of references in order to answer to the research problem and the research questions. The interview guide used was read and commented by several other persons in order to test the comprehension of the questions and in order to improve the formulation of the questions. The interview was conducted face-to-face in order to gain better understanding of the situation and to be able to explain the possible misunderstandings of the questions. The interview guide was sent to the respondent via e-mail few days before the actual interview in order to let the respondents to read through the questions and prepare somewhat their answers. The aim of the personal interview was to obtain comprehensive answers from the respondents' side and to let the respondents to describe the entire research area from their point of view. Considerable efforts were made in order to find the most suitable and knowledgeable respondents, who were competent and capable to answer the interview questions within the company selected. The time aspect was also considered and a telephone interview, as a shorter type of interview, did not feel like a suitable option for this research. Careful notes were made during the whole interview and in order to ensure the validity, the whole interview was recorded and the researcher made his own notes, which then later on were conducted together. Multiple sources of evidence, like the interview and other documents, were used during the data collection in order to ensure even further increased validity. The documents were furthermore used to verify the answers given by the respondents.

\section{Choice of Foreign Entry Modes at WISCO}

\subsection{Overview of Wuhan Iron and Steel (Group) Corporation (WISCO)}

Wuhan Iron and Steel (Group) Corporation (hereinafter referred to as WISCO), commenced its construction from 1955, and put into production on Sep. 13, 1958, is the first giant iron and steel complex established after the founding of the People's Republic of China and one of the backbone enterprises under the leadership of the Central Government and the State Council. After its integration and reformation with Echeng Iron \& Steel Company, and Liuzhou Iron \& Steel Company, the group corporation has had an annual production capacity of 20 million tons, ranking the third of the same kind corporation in China, and the sixteenth of the same all over the world. Located in the eastern suburb of Wuhan, Hubei known as “Thoroughfare to Nine Provinces", WISCO sits on the south bank of Changjiang River, covering an area of 21.17 square kilometers. WISCO, the important plate production base in China, owns a complete set of processing plants composed of mining, coking, sintering, iron making, steel making, rolling, and the associated utilities. It has made an important contribution to China's national economy and modernization during some 50-year construction and development. By the end of 2006,

\begin{tabular}{|l|l|}
\hline \multicolumn{2}{|c|}{ Factors Influencing Choice of Foreign Entry Modes } \\
\hline \multicolumn{1}{|c|}{ Internal Factors } & \multicolumn{1}{c|}{ External Factors } \\
- Speed & \\
- Costs & - Socio-cultural distance \\
- Payback & - Country risk/ demand uncertainty \\
- Long-term Objectives & - Market size and growth \\
- Company's size & - Direct/indirect trade barriers \\
- International experience & - Competitive environment \\
- Product & - Small number of relevant export intermediaries available \\
- Risks & - Laws and regulations \\
- Control & - Geographical distance \\
- Flexibility & \\
- Managerial Reasons & \\
- Relationships & \\
\hline
\end{tabular}

Figure 3. Conceptual framework. Source: Authors Construction (2014). 
WISCO has produced 177 million tons of steel with an accumulated profit and tax of 85.4 billion RMB, among which, 59.892 billion RMB handed over to the state, which is 9.3 times of 6.42 billion RMB invested to WISCO by the state.

WISCO started international trade business since 1980 and had a very sound foreign trade agency. The name of the trade agency went from China Metallurgical Import and Export Corporation Wuhan Branch, China Metallurgical Import and Export Corporation WISCO Branch, to China Metallurgical Import and Export Corporation in WISCO Corporation. After Wuhan Iron and Steel Group Corporation were found by the approval of Ministry of Foreign Trade and Economic Cooperation, China, International Economic \& Trading Corporation WISCO (IETC, WISCO) was established on Dec. 31, 1993. And our study was conducted within this department.

\subsection{Choice of Entry Mode at WISCO}

According to Brassington \& Pettitt (2000) [3] and Armstrong G. \& Kotler P. (2005) [5], there are several different modes of foreign market entry: Direct export, Indirect export, Licensing, Franchising, Contracting, Sales subsidiaries, Manufacturing subsidiaries, Joint ventures and Strategic alliances.

WISCO has used five of these modes in their foreign market entry:

$\checkmark$ Direct exporting,

$\checkmark$ Indirect exporting,

$\checkmark$ Contracting,

$\checkmark$ Sales subsidiaries

$\checkmark$ Strategic alliances.

According to Czinkota \& Ronkainen (2004) [9], internationalization process is a gradual process and there are very few companies that initiate exporting from the starting time, even though in some rare cases it is possible to be "born global". However, Albaum, Duerr \& Strandskov (2002) [10] stated that companies do not necessarily always internationalize in an orderly and sequential way. Some companies may stop at a particular stage without proceeding further, some skip stages or even reverse the sequential process by starting their international activities at a later stage. Hollensen (2003) [11] in his turn pointed out that, in recent years an increasing number of companies can be identified that they do not follow the traditional pattern of internationalization process. In contrast, these "born global" companies directly aim at international markets or the global market from the starting of the company.

Kotabe \& Czinkota (1998) [12] has identified four different stages that company should be stepped through in the traditional internationalization process:

Uninterested exporter $\rightarrow$ Partially interested exporter $\rightarrow$ Experimental exporter $\rightarrow$ Experienced exporter.

According to Calof \& Viviers (1995) [13], the more experienced the company becomes on the international markets, the more profitable and less risky the business abroad turns out to be. Czinkota (2001) [14] on the other hand stated that increasing risks on a foreign market are habitually accompanied by declining profitability, at least at the very beginning of the establishment of international activities.

The company of our case study did not follow the traditional pattern of gradual and sequential internationalization process mentioned by Kotabe \& Czinkota (1998) [12]. Nonetheless WISCO cannot be described as a "born global" as Farhang (2001) [15], since they had not been involved in the international nor global market from the very start of their establishment. During the first 22 years WISCO has been producing and selling exclusively in Chinese domestic market and the company did not have any aims to go internationally. However, in 1980, on their government initiative, as well as to obtain foreign currency by importing foreign technology and equipment, WISCO has started direct exports to Europe, USA, Canada, Australia, Hong Kong, Korea and India. WISCO also has never got an unsolicited order from Europe and has not been following the different stages in the traditional and gradual internationalization process. Since the starting of the exports to Europe, WISCO has also become interested to join in the long term competition in the global market and become a world renowned company. At present, WISCO is a successful international company that is more export dependent and the company exports approximately 13.4 percent of their sales.

It can be stated that WISCO at present is a highly experienced company within the global markets in view of the fact that they have been exporting over 20 years. The more experienced WISCO has become, the less risky the business abroad has turned out to be, as Calof \& Viviers (1995) [13] pointed out. 
It could be natural for WISCO to go international and export within the Asian countries due to the geographical closeness of the markets and the similarities in traditions, culture and language as mentioned by Johansson \& Vahlne (1977) [16]. But in general WISCO do not consider the socio-culturally and geographically close markets as less risky to enter. However, it should be noted that it had took over 20 years on direct exporting before the company decided to invest a sales subsidiary abroad.

\subsection{External Factors Influencing Choice of Foreign Entry Modes at WISCO}

Socio-cultural distance has no importance for WISCO's choice of foreign entry mode. This is conflicting with Hollensen (2001) [6] stated that countries that have similar business and industry practices, language and cultural characteristics, as well as comparable educational levels are socio-culturally close to each other, great differences within these factors may influence the company's decision of mode of entry greatly.

Country risk and demand uncertainty are important factors to take into consideration when choosing foreign entry modes for WISCO. The company acted on several foreign markets for a long time before the decisions about the new sales subsidiary was determined. Good knowledge and information about the market are crucial according to WISCO in determining which entry mode to use and in what extent to involve in the foreign market both concerning level of investments and risks. These factors are considered importantly also according to Hollensen (2001) [6].

Market size and growth are also high importance for WISCO's choice of foreign entry mode. This factor has very much affected where the location of the new sales subsidiary in where to be placed. The more market potential, the more investments are made. These factors are also considered importantly according to our existing theories [6] and Dahringer \& Mühlbacher (1991) [17] also emphasized on the importance of these factors.

Direct and indirect trade barriers do also affect the choice of foreign entry mode for WISCO. The company considers overwhelming trade barriers exist on the international markets where WISCO is conducting business. These factors are also considered importantly according to our existing theories [6] and Jobber \& Whitelock (1994) [18].

Competitive market does play an important role in choosing foreign entry modes for WISCO. This factor is also considered importantly according to our existing theories [6] and Lewis \& Richardson (2001) [19].

Small number of relevant export intermediaries available is of no importance for WISCO's choice of foreign entry mode. The ability to gain good relationships with the sales representatives and contractors on the foreign markets has always been of high importance for the company. This is conflicting with our existing theories [6] and Jobber (2004) [20].

Laws and regulations have importance when choosing foreign entry mode for WISCO. The companies that enter these markets have to adapt for the existing laws and regulations. These factors are also considered importantly according to our existing theories, De Búrca, Brown \& Fletcher (2004) [1] pointed out that in some international markets, laws and regulations within the target country may prevent or restrict imports into the target market or only permit local manufacturing in less attractive geographical locations. Furthermore the form of entry mode may also be regulated or prescribed by the government of the target country.

Geographical distance is not significant for WISCO's choice of foreign entry mode, as the company started to set up sales subsidiary in European market in first time instead of neighboring Asian countries. This is conflicting with our existing theories which stated that when the geographical distance is great, transportation costs may become too high and make it impossible to compete against the local goods in the target market, according to Root (1994) [2].

\subsection{Internal factors Influencing Choice of Foreign Entry Modes at WISCO}

Speed is not a key factor for WISCO's choice of foreign entry mode. It is not important for the company to gain revenues and profits relatively fast when entering a new market. This is conflicting with our existing theories, Brassington and Pettitt (2000) [3] pointed out that depending on choice of entry mode, the time of reaching the target market may vary; some market entry modes might take months or years to implement, while others can be put into action in few time.

Costs were in the beginning of WISCO internationalization of high importance. This factor influenced the choice of entry mode to a high extent in the beginning of the company's internationalization. However, with the company's current economic state, which is excellent, it is no longer equally important. These are in the same 
line with our existing theories [3].

Flexibility is not important for WISCO's choice of foreign entry mode. This is conflicting with our existing theories which consider Flexibility as also important factor for choice of foreign entry mode [3].

Risks are of high significance when choosing foreign entry modes for WISCO. It is important to be able to manage risks and to act in a right way when facing risk situations. The choice of mode of entry is highly connected to the level of risks taken. These are in the same line with our existing theories [3].

Payback does play an important role in WISCO's choice of foreign entry mode. This is in the same line with our existing theories which stated that payback time for the company's investment can be crucial when an organization enters a foreign market [3].

Long-term objectives are of high importance when choosing foreign entry modes for WISCO. These are in the same line with our existing theories, the organization must know what it wants to achieve in the future and how it best can exploit the opportunities available in the foreign market. The choice of entry mode is just the first stage in a longer-term strategic plan for the international markets [3].

Company size does not affect WISCO's choice of foreign entry mode. This is conflicting with our existing theories, according to Hollensen (2001) [6] the size of a company indicates the company's resource availability. The larger the company is, the better resources it has for the foreign involvement.

International experience is not important when choosing foreign entry modes for WISCO. This is conflicting with our existing theories which stated that previous international experience of the company and managers influence highly the choice of entry mode [6].

Type of product plays a key role in WISCO's choice of foreign entry mode. Due to the direct and indirect export through sales representatives and sales subsidiaries have been natural choices. This is in the same line with our existing theories which stated that when deciding where the production should be located, the physical characteristics of a product or service are highly important to take into consideration [6].

Planning and control are not important when WISCO chooses their foreign entry modes. These are conflicting with our existing theories which stated that when deciding about the entry mode, the degree of control that the company requires over international operations has to be taken into consideration. The level of control is often highly linked to the level of resource commitment abroad [6].

Managerial reasons are also not significant when choosing foreign entry modes for WISCO. The company is a state owned company and the management influence is very less in every choice made by the company. These are conflicting with our existing theories, De Búrca, Brown \& Fletcher (2004) [1] stated that the previous experiences of international markets of the company's management influence highly the choice of foreign entry mode.

Relationships are not also important for WISCO's choice of foreign entry mode. However, good contacts and relations are needed in order to find suitable sales representatives, advertising agencies and entrepreneurs in the foreign markets. These are conflicting with our existing theories, according to Fredrik \& Webster (1992) [7] the different types of relationships that a company can have, among others with its suppliers and customers are highly connected with the selection of a particular foreign entry mode.

\section{Conclusions and Findings}

The purpose of this research is to increase our understanding of how the process of internationalization is intertwined with the set of external and internal factors that determine choice of foreign entry mode. To satisfy the purpose of our study, the following research questions were addressed:

RQ: How can the influence of external and internal factors on WISCO’s choice of foreign entry mode be described?

Data collected on the company WISCO that was analyzed against existing theories brought us to certain conclusions which we present below. The fact that a single case would not allow us to generalize is not overlooked. However, in-depth analysis of the company WISCO has shed light on aspects of internationalization choice of entry modes which deserve consideration.

\section{How Can the Influence of External and Internal Factors on WISCO's Choice of Foreign Entry Mode Be Described?}

According to existing theories, the international entry strategy is a comprehensive plan and it sets forth objectives, goals, resources and policies that will guide a company's international activities. A company's entry 
strategy is not a single plan; it is actually a composite of several individual product/market plans. The selection of a foreign entry mode is affected by other decisions that may include the following:

1) Choice of a target/product market

2) Objectives and goals in the target market

3) Choice of an entry mode to penetrate the target market country

4) Marketing plan to penetrate the target market

5) Control system to monitor performance in the target market

The classification of different foreign entry modes is complicated and there are many relevant criteria to take into consideration. Companies often choose neighboring countries to make their first exports due to the similarities in the markets, this reduces risks and cultural patterns are often similar. Trade barriers influence the type of entry mode when a company is initiating export. When product regulations and standards necessitate significant product adaptation and modification, companies often establish local production, assembly or finishing facilities. Foreign governments can also favor products that are produced in the country and can therefore give advantages to companies who choose to make direct investments in the country. The distance to the chosen target market is also a factor to take into consideration. High transport costs can influence a company to conduct a foreign investment. Some market entry modes might take months to implement, while others can be put into action in less time. Sometimes it might be justified to use an entry mode that costs more than another due to higher benefits in the long run, since the choice of entry mode is just the first stage in a strategic plan for the international markets. Different types of entry modes provide different types of risks, control and flexibility. Entry modes with a high involvement on the foreign market like direct investment provide a high control, but also high costs and risks. Depending on the flexibility of product and market is also a factor to take into account. Entry modes with low resource commitment like direct exporting provide low costs but also low control.

The company in our case study, WISCO, has utilized both direct export and direct investments. During the first years of its internationalization, the company used only direct and indirect export. The company did not consider low geographical distance, low or non existing trade barriers and low cultural distance on choosing those types of entry as WISCO started to export to European and the USA market before considering the company neighboring Asian countries. It can be stated that the decision to go international for WISCO was due to the Central Government's politics in order to obtain foreign currency for importing foreign technology and equipment.

The company of our case study, WISCO, does not quite follow the theoretical patterns for choice of foreign entry modes, since the company does not admit the imperative influence of all of these external and internal factors for their selection of foreign entry modes. However, on closer look a great influence of some of these factors can easily be identified.

The company's choice of foreign entry modes in our case study has been primarily influenced by following external factors:

$\checkmark$ Country risk and demand uncertainty

$\checkmark$ Market size and growth

$\checkmark$ Direct and indirect trade barriers

$\checkmark$ Competitive market

$\checkmark$ Laws and regulations

Concerning the influence of internal factors, the company's choice of foreign entry modes in our case study has been primarily influenced by following factors:

$\checkmark$ Costs

$\checkmark$ Risks

$\checkmark$ Payback

$\checkmark$ Long-term

$\checkmark$ Type of product

Since some differences between the theoretical patterns and our case study can be identified, the following can be stated:

$\checkmark$ Our case study shows that each and every company and their situation should be studied individually in order to identify the main external and internal factors that influence the company's choice of foreign entry modes. In fact, this has been a point in support of conducting an in-depth case study.

$\checkmark$ The greater influence of some particular factors may vary depending on the situation of the company studied. 


\section{Acknowledgements}

I would like to express my special thanks to Professor Yan Liang, Dean of School of Economics and Management, for his expertise and professional supervision. I would also like to express all my gratitude to the International Education College, China University of Geosciences (Wuhan) as thanks from Madagascar community, for their support to all Madagascar Students. I also express my special thanks to the government of China and the government of Madagascar for their financial support and to the International Trade and Economics Department of Wuhan Iron and Steel Corporation for heir high collaboration and contributions during this research. And finally, I also express my gratitude to all my family members in Madagascar for their support.

\section{References}

[1] De Búrca, S., Brown, L. and Fletcher, R. (2004) International Marketing: An SME Perspective. 1st Edition, Financial Times Prentice Hall, Harlow, 720 p.

[2] Root, F.R. (1994) Entry Strategies for International Markets. Revised and Expanded Edition, Lexington Books, New York, $324 \mathrm{p}$.

[3] Brassington, F. and Pettitt, S. (2000) Principles of Marketing. 2nd Edition, Financial Times Management, Harlow, 1079 p.

[4] Wild, J.J., Wild, K.L. and Han, J.C.Y. (2003) International Business. 2nd Edition, Prentice Hall, Upper Saddle River, $528 \mathrm{p}$.

[5] Armstrong, G. and Kotler, P. (2005) Marketing: An Introduction. 7th Edition, Prentice Hall, Upper Saddle River, 581 p.

[6] Hollensen, S. (2001) Global Marketing: A Market-Responsive Approach. 2nd Edition, Financial Times Prentice Hall, Harlow, 667 p.

[7] Fredrick, E. and Webster, J. (1992) The Changing Role of Marketing in the Corporation. Journal of Marketing, 56, 1-17.

[8] Yin, R.K. (2003) Case Study Research: Design and Methods. 3rd Edition, Sage Publications, Thousand Oaks, 181 p.

[9] Czinkota, M.R. and Ronkainen, I.A. (2004) International Marketing. 7th Edition, Thomson Learning, Mason, 666 p.

[10] Albaum, G., Duerr, E. and Strandskov, J. (2002) International Marketing and Export Management. 4th Edition, Financial Times Prentice Hall, Harlow, 637 p.

[11] Hollensen, S. (2003) Marketing Management: A Relationship Approach. Financial Times Prentice Hall, Harlow, 787 p.

[12] Kotabe, M. and Czinkota, M.R. (1992) State Government Promotion of Manufacturing Exports: A Gap Analysis. Journal of International Business Studies, 23, 637-658.

[13] Calof, J.L. and Viviers, W. (1998) Internationalization Behavior of Small and Medium Sized South African Enterprises. Blackwell Publishing, Malden.

[14] Czinkota, M.R. (2001) A National Export Assistance Policy for New and Growing Businesses. In: Czinkota, M.R. and Ronkainen, I.A., Eds., Best Practices in International Business, South-Western Publishing Co., Cincinnati.

[15] Farhang, M. (2001) Internet and Export Marketing of SMEs: Experiences of Website Use and Perceptions among Swedish Firms. Research Report, Luleå University of Technology, Luleå, 40 p.

[16] Johansson, J. and Vahlne, J.E. (1977) The Internationalization Process of the Firm—A Model of Knowledge, Development and Increasing Foreign Market Commitment. Journal of International Business Studies, 8, 23-32. http://dx.doi.org/10.1057/palgrave.jibs.8490676

[17] Dahringer, L.D. and Mühlbacher, H. (1991) International Marketing: A Global Perspective. Addison-Wesley Publishing Company Inc., Reading, 677 p.

[18] Jobber, D. and Whitelock, J. (1994) The Impact of Competitor Environment on Initial Market Entry in a New, NonDomestic Market. Proceedings of the Marketing Education Group Conference, Coleraine, 4-6 July 1994.

[19] Lewis III, H. and Richardson, J.D. (2001) Why Global Commitment Really Matters! Institute for International Economics, Washington DC.

[20] Jobber, D. (2004) Principles and Practice of Marketing. 4th Edition, McGraw-Hill International Ltd., Berkshire, 942 p. 
Scientific Research Publishing (SCIRP) is one of the largest Open Access journal publishers. It is currently publishing more than 200 open access, online, peer-reviewed journals covering a wide range of academic disciplines. SCIRP serves the worldwide academic communities and contributes to the progress and application of science with its publication.

Other selected journals from SCIRP are listed as below. Submit your manuscript to us via either submit@scirp.org or Online Submission Portal.
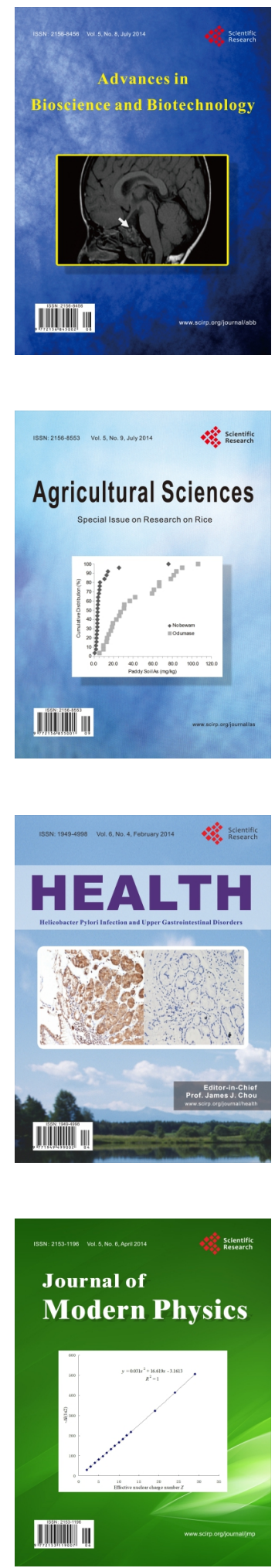
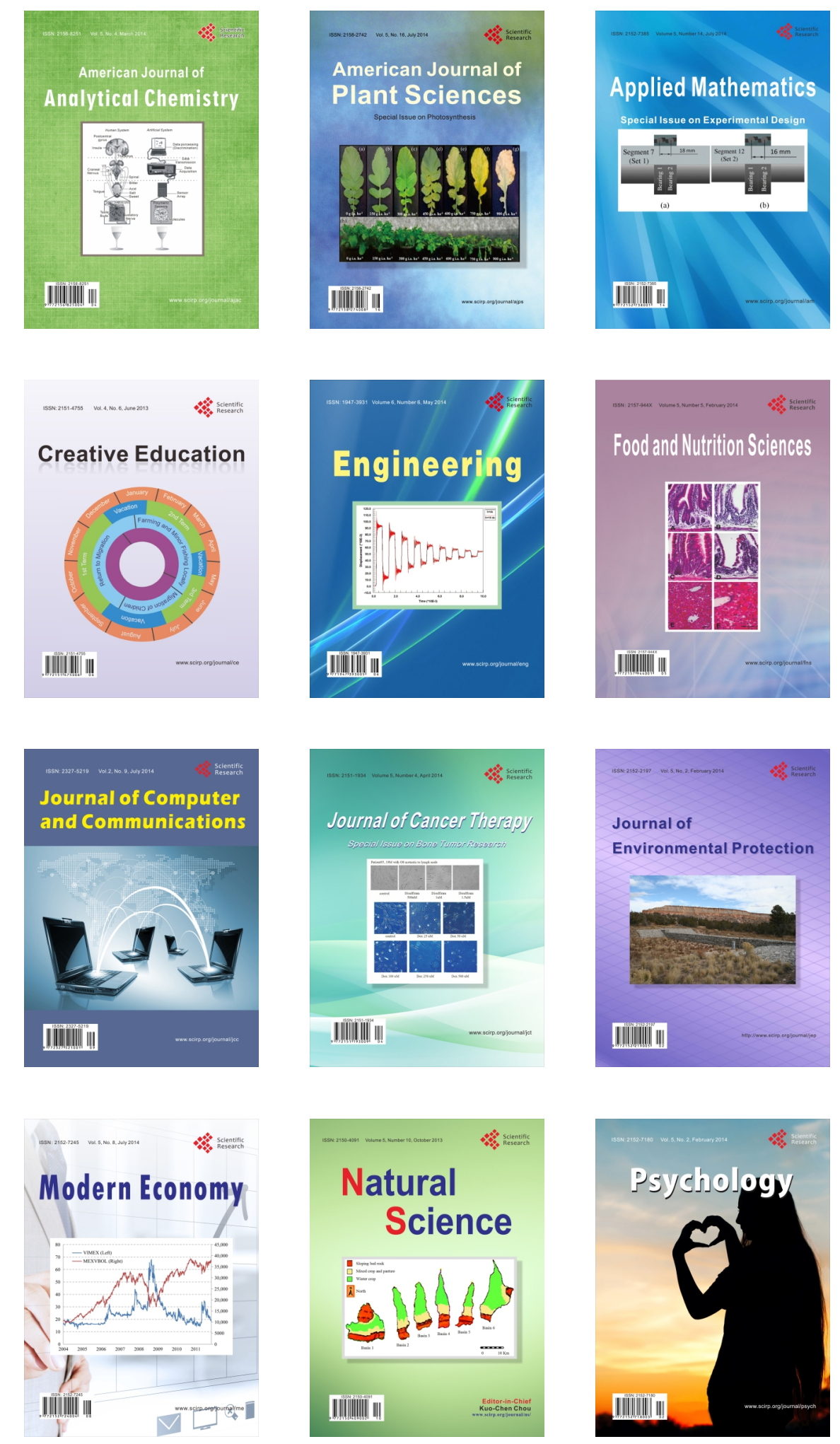